\title{
Dynamic and static behavior of a steel covered column
}

\author{
B. Sevim* \\ Ylldız Technical University, Department of Civil Engineering, 34220, Istanbul, Turkey
}

\begin{abstract}
Composite columns are used to increase the strength for a given cross sectional dimension; stiffness leading to reduced slenderness and buckling resistance, corrosion and fire resistance in the case of concrete encased columns. Also, they provide a formwork for concrete filled steel tubes and economical solutions with regard to material costs. They are effectively started to use in the world. This study presents the dynamic and static behavior assessment of a steel covered column. In the content of the study, full concrete filled rectangular steel tube column as a composite column is selected for numerical analysis and its finite element model is constituted using ANSYS software. Dynamic behavior of the model is obtained performing modal analysis. The natural frequencies and mode shapes are obtained as dynamic characteristics to understand dynamic behavior. Then the model is statically performed. In static analysis, both of vertical and lateral loads are applied to models. The displacement and stress changes in some critical nodes and sections and contour diagrams are reported by graphs and figures after static analysis.
\end{abstract}

\section{Keywords}

Dynamic and static behavior; Finite element modeling; Full concrete filled rectangular steel tube; Steel covered column

Received: 16 March 2018; Accepted: 29 March 2018

ISSN: 2630-5763 (online) @ 2018 Golden Light Publishing ${ }^{\circledR}$ All rights reserved.

\section{Introduction}

Composite elements are economical materials and they provide quicker construction which makes more preferable than conventional RC elements. However, the main disadvantages of composite elements are the problems on the connection of complicated joint of column-RC beam and lower steel-fire and corrosion resistant. But the main reason to use these elements are specified as that the higher axial load capacity, better ductility performance, larger energy absorption capacity, and lower strength degradation [1,2]. In addition, steel tube as a part of composite element provides confining effects to concrete to behave in a tri-axial compressive stress state while concrete prevents the steel tube for from buckling inward [3-6]. The composite columns are generally classified considering concrete filled, circular or rectangular and steel covered with one or double skin types [79].

Zhao et al. [10], investigate the axial compression performance of steel/bamboo composite column. In that study, new type of thinwalled steel tube/bamboo plywood hollow composite column with binding bars (SBCCB) used transverse binding bars to reinforce the composite column was developed. The compression performance of four specimens with larger slenderness ratio was tested to examine the failure mode of the SBCCBs. Chen et al. [11] studied about the effects of steel-to-member depth

\footnotetext{
*E-mail: bsevim18@hotmail.com
} 
ratio and axial load on flexural ductility of concrete-encased steel composite columns. In that study, the composite columns were tested under cyclic loading with various axial load levels. In addition to the axial load level, effects of steel-tomember depth ratios on flexural behavior of encased composite members were investigated. Two types of concrete-encased steel composite specimens were designed to represent two steel-tomember depth ratios. Ma et al. [12] examined the compressive behavior of composite columns composed of RAC-filled circular steel tube and profile steel under axial loading. the compressive behavior of composite columns on the basis of the axial compression tests of eleven specimens under uniaxial loading were investigated. The design parameters of the columns in the tests were recycled coarse aggregates (RCA) replacement percentage, diameter-thickness ratio of circular steel tube, profile steel ratio and slenderness ratio. The failure process and modes, load-displacement curves, Poisson's ratio of circular steel tube, characteristic loads and ductility of composite columns were presented and analyzed. Denavit et al. [13] presented a paper related to elastic flexural rigidity of steel-concrete composite columns. The behavior of composite columns was characterized at the cross section and member levels through comparisons between inelastic and elastic analyses. Then, through a broad parametric study, specific practical design recommendations were developed for the elastic flexural rigidity of composite columns for the determination of lateral drifts under service loads.

Table 1. Materials properties of the columns

\begin{tabular}{lll}
\hline \multirow{2}{*}{ Material properties } & \multicolumn{2}{c}{ All columns } \\
\cline { 2 - 3 } & Concrete & Steel Tube \\
\hline Weight per unit volume $\left(\mathrm{kg} / \mathrm{m}^{3}\right)$ & 2400 & 7850 \\
Young's modulus $\left(\mathrm{N} / \mathrm{m}^{2}\right)$ & $3 \mathrm{E} 10$ & $2.1 \mathrm{E} 11$ \\
Poisson's ratio & 0.2 & 0.3 \\
\hline
\end{tabular}

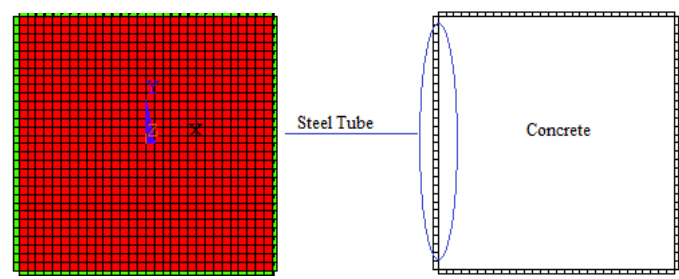

Fig. 1. Section of the steel covered column

The many regions in the world are earthquakeprone area, so composite elements should be used to build structures in these regions. So, considering the importance of composite structures and the lack of literature, more studies must be done to investigate the structural response. In the study, it is investigated that the dynamic and static behavior of a steel covered column as a rectangular composite column under vertical and lateral loads. For the purpose, a full concrete filled circular steel tube column in 3D is constituted by ANSYS software [14]. Then, modal analysis is performed to obtain dynamic characteristics and the static analysis is performed under vertical and lateral loads. The displacement and stress changes in some critical nodes and sections and contour diagrams are reported by graphs and figures.

\section{Numerical example}

\subsection{Description of the steel covered column}

Numerical example contents the dynamic and static analyses of a full concrete filled rectangular steel tube column as steel covered column, the crosssection of the column is seen in Fig. 1. In the study, the height of the column is selected as $3 \mathrm{~m}$ and both of width and depth of concrete part is assumed as $30 \mathrm{~cm}$. The wall thickness is considered as $6 \mathrm{~mm}$. the concrete material is selected as $\mathrm{C} 30$, the steel tube material is assumed as S420. The material properties of the column used dynamic and static analyses are listed in Table 1.

\section{2. $3 D$ finite element modeling of the column}

3D finite element model of the rectangular column is built using ANSYS software [14] (See Fig. 2a). In the modeling, the concrete and steel tubes are 
considered using SOLID65 and SHELL181. elements, respectively. Here, the SOLID65 element has 8 nodes, with each node having three translational degrees of freedom (Fig. 3); and the SHELL181 element has 4 nodes, with each node having three translational and rotational degrees of freedom (Fig. 3). 45000 SOLID65 element for concrete modeling, and 6000 SHELL181 elements for steel tube are used to represent suitable column model. Also mesh refinements studies are done to decide the optimum finite element model. In the study, each finite element is connected to each other with nodal points without considering contact surfaces between individual concrete and steel tube units. In defining the boundary conditions, all degrees of freedom under the columns were assumed as fixed. In the study, model analysis of the column is performed to obtain natural frequencies and mode shapes to assess the dynamic behavior. Also, linear analysis is performed under lateral and vertical loads to understand static behavior. K, L, and L' points and I-I section given as schematically in Fig. $2 \mathrm{~b}$ are used to present the displacement and stress changing obtained from linear analysis.

\subsection{Modal analysis of the column}

The modal analyses of the column are performed and the natural frequencies and mode shape are illustrated in Fig. 4. As is seen in Fig 4 that the first 11 natural frequencies change between $43-790 \mathrm{~Hz}$. Also, mode shapes are obtained as lateral bending modes and torsional modes. Natural frequencies of lateral modes are equal to each other due to symmetry. The dynamic characteristics show that the composite column has 2-3 times more rigidity than conventional RC models. Because first natural frequency of a conventional column with same material and geometrical properties, and boundary conditions is about $18 \mathrm{~Hz}$.

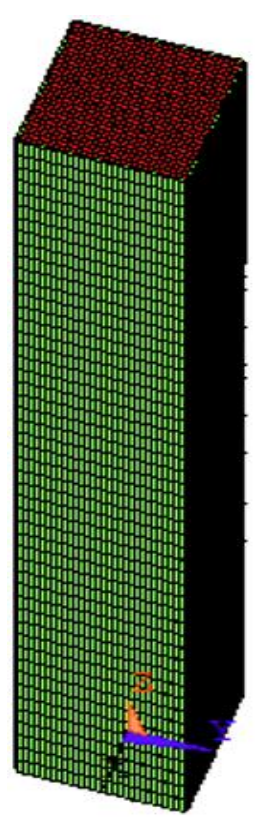

a)

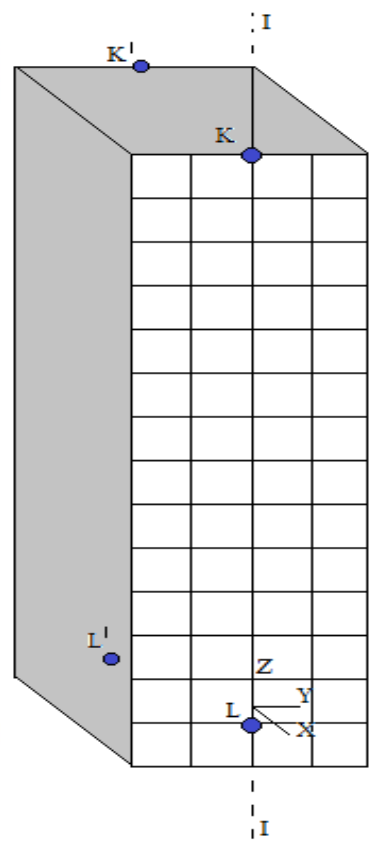

b)
Coordinates

$\begin{array}{ll}\mathrm{K}(0.15 ; 0.00 ; 3.00) & \mathrm{L}(0.15 ; 0.00 ; 0.24) \\ \mathrm{K}^{\prime}(-0.15 ; 0.00 ; 3.00) & \mathrm{L}^{\prime}(-0.15 ; 0.00 ; 0.24)\end{array}$

Note: Units are "m"

Fig. 2. a) Three-dimensional finite element model of the steel covered column, b) schematic view of points and section where the results are presented
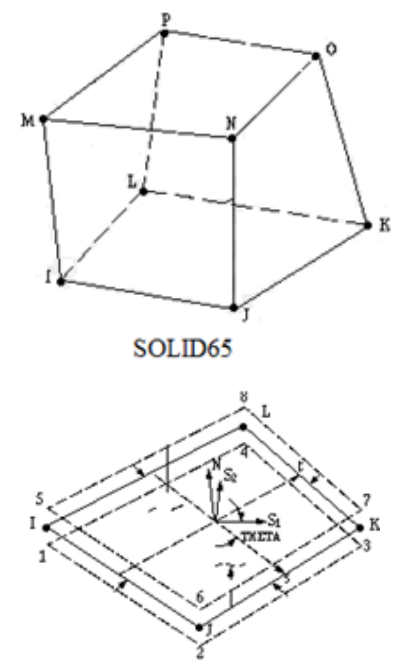

SHELL181

Fig. 3. Element types used in the modeling 

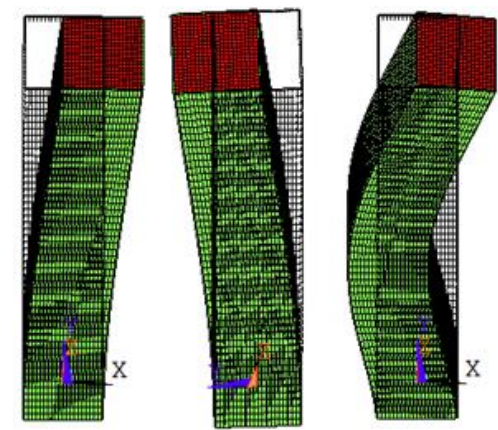

$$
\begin{gathered}
\mathrm{f} 1=43.7 \mathrm{~Hz} \\
\text { Mode } 1
\end{gathered}
$$

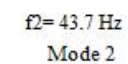

$\mathrm{f} 3=239.0 \mathrm{~Hz}$
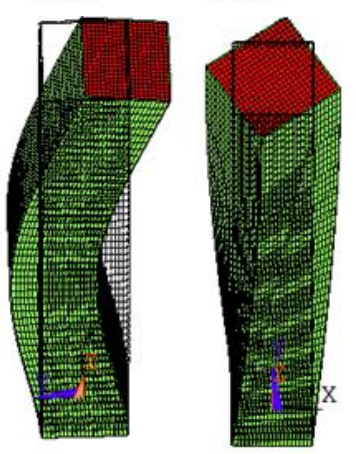

Mode 3

$\mathrm{f} 4=239.0 \mathrm{~Hz}$ Mode 4

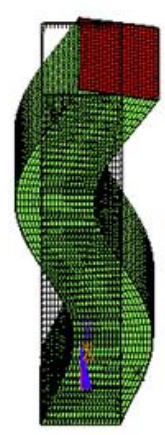

$\mathrm{f} 7=577.0 \mathrm{~Hz}$

Mode 7

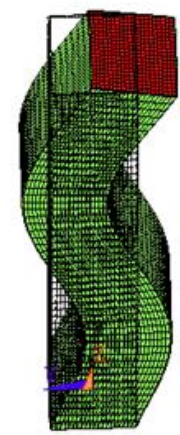

$\mathrm{f} 8=577.0 \mathrm{~Hz}$ Mode 8

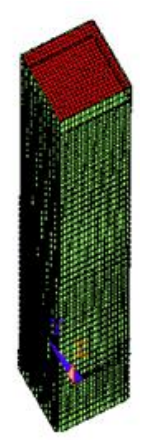

f6 $=400.5 \mathrm{~Hz}$

Mode 6

$\mathrm{f} 9=848.4 \mathrm{~Hz}$

Mode 9

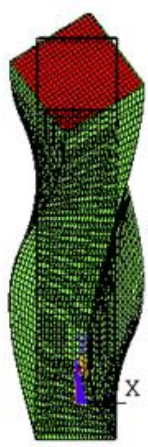

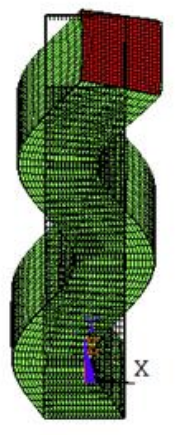

$\mathrm{f} 10=970.0 \mathrm{~Hz}$ Mode10

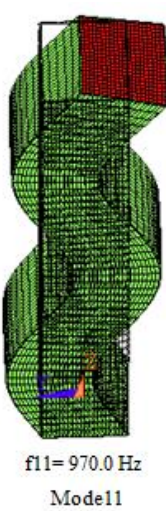

Mode11

Fig. 4. Natural frequencies and mode shapes of the model

\subsection{Static analysis of the column}

In the study, $30 \mathrm{MPa}$ stress as the vertical static load and $1520 \mathrm{kN}$ single load as the lateral load are applied to model. The vertical load is applied as pressure on the top area of the columns for only one step. Then, under the initial conditions, lateral loads are applied to as single loads on all nodes at the top surface of the columns.

The force-displacement curve and displacement changing along to height of the column are plotted in Fig. 5a-b, respectively. As is seen in Fig. 5a, 23 $\mathrm{mm}$ displacement occurs from linear static analysis. According to Fig. 5b, the displacements are increased along to height of the column. According to maximum lateral displacement $(23 \mathrm{~mm})$ under $1520 \mathrm{kN}$ lateral load, the relative displacement ratio is about 0.008 which provides a safer column than a conventional RC column.
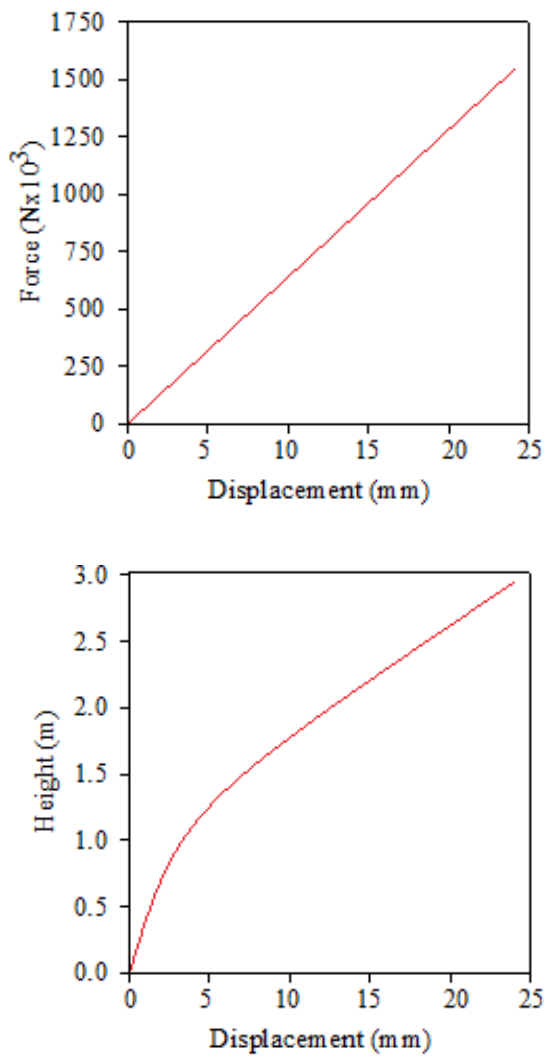

Fig. 5. a) Force-displacement curve on $\mathrm{K}$ point and b) changing of displacements along to I-I- section obtained from the model 


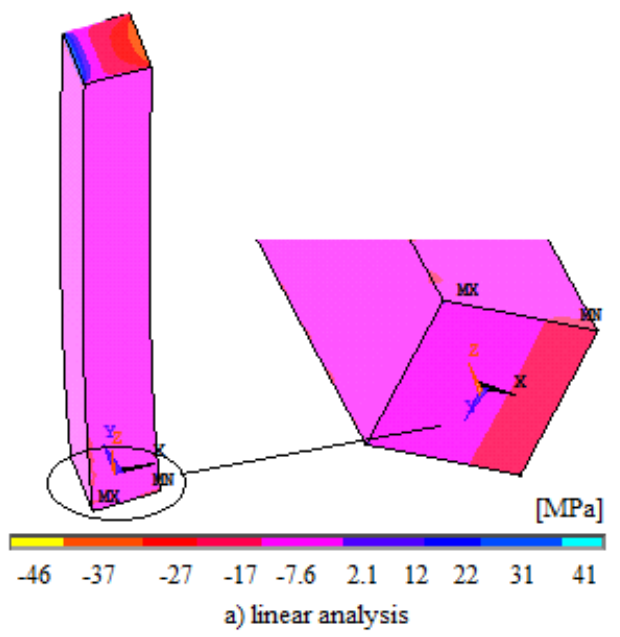

Fig. 6. The inhomogeneous orthotropic rectangular plate on the elastic foundation and the coordinate system
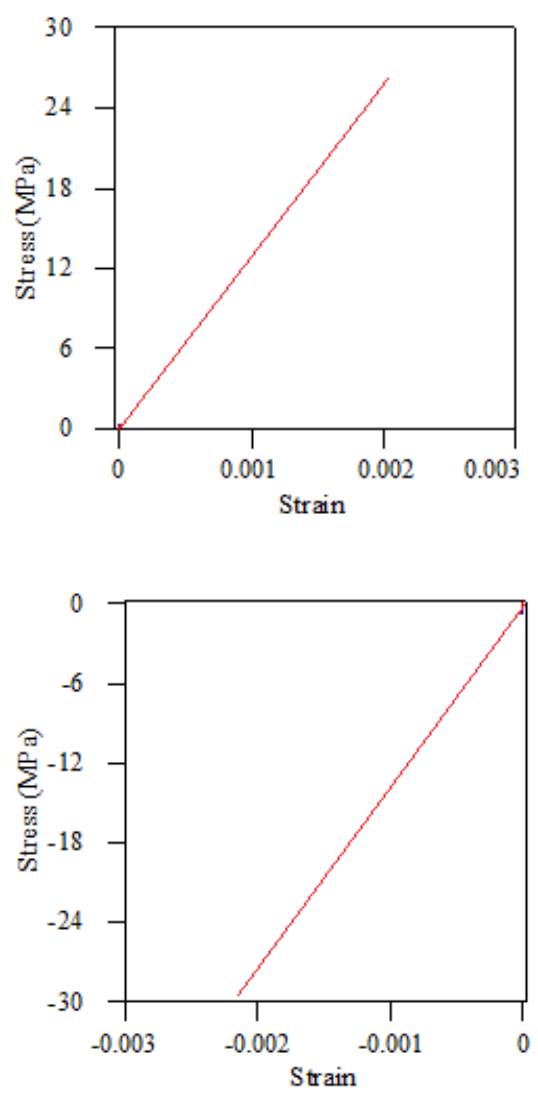

Fig. 7. a) Maximum stress-strain curve on L' point and b) Minimum stress-strain curve on L point obtained from the model
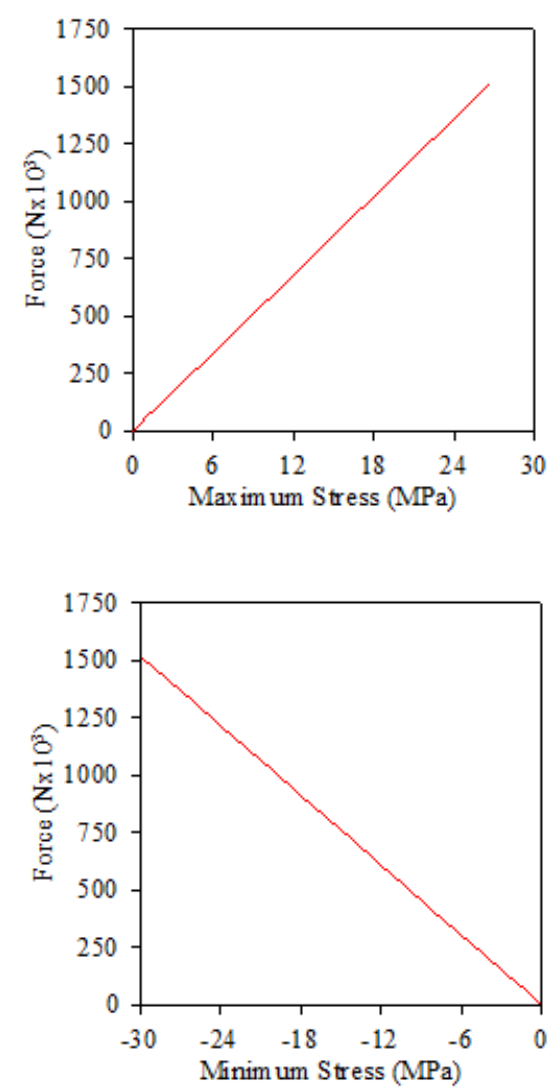

Fig. 8. a) Force-maximum stress curve on L' point and b) Force-minimum stress curve on L point obtained from the model

$\mathrm{S}_{\mathrm{x}}$ contour diagram obtained from linear analysis of the column is illustrated in Fig. 6. As is seen from Fig. 6 that extreme values are obtained at the top where loads are applied and the bottom of the column around the steel tube. Also, the model provides safety considered strength of steel and concrete. Maximum and minimum stress-strain curves are plotted in Fig. 7a-b, respectively obtained from linear analysis of the column. The force-stress relation obtained on $\mathrm{L}^{\prime}$ and $\mathrm{L}$ points are plotted in Fig. 8a-b, respectively. The minimum and maximum strains under stresses are suitable for both concrete and steel material. Also, the minimum and maximum stresses under maximum forces are lower than both strength of concrete and steel material. 


\section{Conclusion}

This study investigates the dynamic and static behavior of a steel covered column as a rectangular composite column under vertical and lateral loads. For the purpose, a full concrete filled circular steel tube column in 3D is constituted by ANSYS software. Then, modal analysis is performed to obtain dynamic characteristics and the static analysis is performed under vertical and lateral loads. According to the study fallowing conclusions are obtained:

- The first 11 natural frequencies change between 43-790 Hz. Also, mode shapes are obtained as lateral bending modes and torsional modes.

- The dynamic characteristics show that the composite column has 2-3 times more rigidity than conventional RC models. Because first natural frequency of a conventional column with same material and geometrical properties, and boundary conditions is about $18 \mathrm{~Hz}$.

- The displacements obtained from linear static analyses are increased along to height of the column. Also, maximum $23 \mathrm{~mm}$ lateral displacement occurs under $1520 \mathrm{kN}$ lateral load. The relative displacement ratio is about 0.008 which provides a safer column than a conventional column.

- The minimum and maximum strains under stresses are suitable for both concrete and steel material. Also, the minimum and maximum stresses under maximum forces are lower than both strength of concrete and steel material.

\section{References}

[1] Patidar AK (2012) Behaviour of concrete filled rectangular steel tube column. IOSR Journal of Mechanical and Civil Engineering 4(2):46-52.

[2] Liu J (2013) Neural networks method applied to the property study of steel-concrete composite columns under axial compression. International Journal on Smart Sensing and Intelligent Systems 6(2):548566.

[3] Sakino K, Nakahara H, Morino S, Nishiyama I (2004) Behavior of centrally loaded concrete-filled steel-tube short columns. Journal of Structural Engineering 130(2):180-188.
[4] Chen Z, Lei J, Zheng Z. Research on CCRST columns used in seismic regions. The 14th World Conference on Earthquake Engineering October 12-17, Beijing, China. 2008.

[5] Karimi K, Tait MJ, El-Dakhakhni WW (2011) Testing and modeling of a novel FRP-encased steel-concrete composite column. Composite Structures 93:1463-1473.

[6] Fakharifar M, Chen G, Lin Z, Woolsey ZT. Behavior and strength of passively confined concrete filled tubes. Proceedings of the 10th National Conference in Earthquake Engineering, Earthquake Engineering Research Institute, Anchorage, 2014.

[7] EssopJournalee Y, Dundu YM (2015) Performance of concrete-filled double-skin circular tubes in compression. Composite Structures 133:12761283.

[8] Ajel HA, Abbas AM (2015) Experimental and analytical investigations of composite stub columns. International Journal Innovative Research in Science, Engineering and Technology 4(2):185200.

[9] Sevim B (2017) Structural response of rectangular composite columns under vertical and lateral loads. Steel and Composite Structures 25(3):287-298.

[10] Zhao W, Chen Z, Yang B (2017) Axial compression performance of steel/bamboo composite column. Procedia Engineering 210:1823.

[11] Chen CC, Chen CC, Shen, JH (2018) Effects of steel-to-member depth ratio and axial load on flexural ductility of concrete-encased steel composite columns. Engineering Structures 155:157-166.

[12] Ma H, Dong J, Liu Y, Guo T (2018) Compressive behavior of composite columns composed of RACfilled circular steel tube and profile steel under axial loading. Journal of Constructional Steel Research 143:72-82.

[13] Denavit MD, Hajjar JF, Perea T, Leon RT (2018) Elastic flexural rigidity of steel-concrete composite columns. Engineering Structures 160:293-303.

[14] ANSYS 2016. Swanson Analysis System, USA. 